Vol. 3 No. 1, Hal 45-48, Oktober 2021

\title{
Analisis Bahan Bakar Campuran Methanol dengan Minyak Jarak terhadap Performa Engine 0S 4.6LA Pesawat Terbang Unmanned Aerial Vehicle (UAV)
}

\author{
Sotya Anggoro* \\ Teknologi Mesin, Program Vokasi Universitas Muhammadiyah Yogyakarta \\ Jl. Lingkar Selatan, Tamantirto, Kasihan, Bantul \\ *Penulis korespondensi: anggapmy@gmail.com
}

Histori artikel: diserahkan 07 Oktober 2021, direviu 10 Oktober 2021, direvisi 20 Oktober 2021

\begin{abstract}
Technological progress is evidenced by the creation of sophisticated equipment made to simplify human life. One of the advanced equipment continuously developed is an uncrewed aircraft called the Unmanned Aerial Vehicle (UAV). This study used an Unmanned Aerial Vehicle (UAV) Super Heavy aircraft with a two-stroke engine type OS 4.6 LA where the two-stroke engine requires fuel which can also lubricate the piston while operating. The purpose of this research is to make an alternative fuel with a mixture of methanol and castor oil where castor oil has flammable properties like fuel in general but can provide better lubrication. In this research, an analysis of the mixture of methanol and castor oil will be carried out on engine performance and fuel consumption of an Unmanned Aerial Vehicle (UAV) aircraft with an engine type OS 4.6 LA. This research aims to compare methanol and castor oil with a ratio of $3: 1$ and 4:1, then test engine performance and fuel consumption. The results confirm that a 4: 1 mixture is the best performer with a stationary rotation of $4184 \mathrm{rpm}$, an idle rotation of $7344 \mathrm{rpm}$, and an acceleration rotation or the highest rotation of $12649 \mathrm{rpm}$. Then the fuel efficiency in the idle position with a flight time of 9.00 minutes consumes $100 \mathrm{ml}$ of fuel, or in other words, the fuel consumption is $11.11 \mathrm{ml} /$ minute.
\end{abstract}

Keywords: Methanol, Castor Oil, Unmanned Aerial Vehicle fuel

DOI : https://doi.org/10.18196/jqt.v3i1.12947

WEB : https://journal.umy.ac.id/index.php/qt/article/view/12947

\section{PENDAHULUAN}

Energi tak terbarukan didefinisikan sebagai energi yang diperoleh dari sumber daya alam yang waktu pembentukannya sampai jutaan tahun. sumber energi tersebut tidak tersedia secara terus menerus, tidak kerkesinambungan, dan pada saatnya sumber energi tersebut akan habis. Dikatakan tak terbarukan karena, apabila sejumlah sumbernya dieksploitasikan, maka untuk mengganti sumber sejenis dengan jumlah sama, baru mungkin atau belum pasti akan terjadi jutaan tahun yang akan datang. Hal ini karena, disamping waktu terbentuknya yang sangat lama, cara terbentuknya lingkungan tempat terkumpulkan bahan dasar sumber energi inipun tergantung dari proses dan keadaan geologi saat itu.

Sumber-sumber energi tak terbarukan keluar dari tanah sebagai cairan, gas, dan padat. Minyak mentah (petroleum) adalah satu- satunya bahan bakar tak terbarukan komersial yang secara alami dalam bentuk cair (Kholiq, 2015). Minyak bumi atau minyak mentah merupakan senyawa hidrokarbon yang berasal dari sisa-sisa kehidupan purbakala (fosil), baik berupa hewan, maupun tumbuhan. Gas alam dan propana biasanya berbentuk gas, dan batubara adalah padat (Manan, 2009).

Pesawat jet menggunakan bahan bakar yang disebut Avation Turbine Fuel atau Avtur, adalah jenis bahan bakar penerbangan yang dirancang untuk digunakan untuk pesawat yang menggunakan turbine gas pada pesawat jet. Bahan bakar pesawat untuk mesin balingbaling biasanya disebut avgas termasuk bahan bakar dalam Internal Combustion. Sumber pencemaran udara akibat emisi gas buang Avtur berupa gas $\mathrm{CO}$, Chlorofluorocarbons dan $\mathrm{CO}_{2}$, dapat merusak lapisan ozon. Salah satu teknologi yang telah dikembangakan saat ini yaitu termoakustik engine (Anugrah, 2018). 
Teknologi tersebut dapat mengatasi permasalahan sumber energi tak terbarukan.

Bahan bakar yang dipakai pada pesawat prototype atau pesawat kecil yang menggunakan mesin 2 tak adalah methanol. Methanol merupakan molekul alkohol paling sederhana dengan rumus kimia $\mathrm{CH}_{3} \mathrm{OH}$ memiliki aplikasi yang sangat luas. Methanol digunakan secara terbatas untuk pembakaran mesin internal, methanol murni dibutuhkan oleh aturan yang digunakan dalam camp-cars, truk raksasa, mobil lari USAC (serta midget, modifikasi, dll), dan dirt track seri lainnya seperti sepeda motor Speedway. Penggunaan bahan bakar yang tidak terbarukan masih mendominasi, sehingga diperlukan bahan bakar alternatif yang bersifat terbarukan yang bersumber dari sumber daya alam. Salah satu hasil alam yang dapat dipakai sebagai bahan bakar adalah minyak jarak.

Minyak jarak adalah minyak nabati yang diperoleh dari ekstraksi biji tanaman jarak $(s)$ yang dikenal pula sebagai minyak kastroli dalam bidang farmasi. Minyak ini serba guna dan memiliki karakter yang khas secara fisik yang tersusu. Pada suhu ruang minyak jarak berfasa cair dan tetap stabil pada suhu rendah maupun suhu sangat tinggi. Bahkan sebagai salah satu sumber energi alternatif, Biodiesel dari tanaman jarak dapat dikategorikan sebagai sumber energi ramah lingkungan. Menurut Warsita (2012), pembakaran mesin yang berbahan bakar biodiesel menghasilkan emisi gas buang, asap dan partikel, yang lebih rendah. Angka cetane yang lebih tinggi dibandingkan solar membuat kadar emisi gas karbon, nitrogen, dan sulfur lebih rendah (Hendriarto et al., 2016).

Mesin penggerak pesawat model secara umum terbagi menjadi dua jenis yaitu engine piston dan engine rotary. Mesin piston mempunyai torak yang bergerak naik dan turun saat ini diproduksi dengan jenis mesin berbusi pijar (glow plug) dengan bahan bakar methanol maupun jenis mesin berbusi percik dengan bahan bakar bensin. Seperti halnya mesin kendaraan bermotor, mesin piston untuk pesawat model juga ada yang berjenis 2 langkah (2 stroke) dan 4 langkah (4 stroke). Pada sisi lain, mesin rotary yang saat ini banyak digunakan untuk pesawat model adalah mesin turbin jet yang berbahan bakar kerosin maupun gas alam. Mesin piston saat ini diproduksi dengan 2 metode pencampuran bahan bakar yang berbeda yaitu dengan karburator dan sistem injeksi bahan bakar (fuel injection system). Tujuan Penelitian ini dilakukan untuk menjawab bagaimana Performa dan konsumsi bahan bakar Engine O.S 4.6 pada Prototype pesawat Unmanned Aerial Vehicle (UAV) Super Heavy dengan menggunakan bahan bakar dari campuran Methanol dengan Minyak Jarak. Pesawat jenis UAV dapat dikendalikan dari jarak jauh melalui dengan remote piloted vehicle (RPV) sejenis perangkat keras dengan sensor (Rachmawati dan Asyam, 2021)

\section{METODE}

Pada penelitian ini dilakukan pencampuran antara methanol dengan minyak jarak. Campuran dibuat dua variasi dengan perbandingan antar methanol dengan minyak jarak 3:1 dan 4:1. Proses pencampuran Methanol dengan minyak jarak di lakukan dengan menggunakan gelas ukur untuk proses pencampurannya.

Campuran bahan bakar ditentukan dan selanjutnya dilakukan pengujian. Pengujian dilakukan dengan menyalakan mesin pada kondisi stasioner, idle dan akselerasi pada throtle. Masing-masing kondisi tersebut diukur putaran mesin permenit atau rpm. Kemudian selanjutnya diukur penggunaan bahan bakar yang dilakukan saat pesawat terbang dengan kondisi throttle pada posisi idle.

\section{HASIL DAN PEMBAHASAN}

Hasil pengujian pada bahan bakar methanol dan minyak jarak dengan perbandingan 3:1 ditunjukkan pada Tabel 1. Hasil kecepatan putaran saat posisi stasioner dengan setelan idle 2.5 menunjukan sekitar $3300 \mathrm{rpm}$, hal ini menunjukan bahwa putaran engine tersebut tinggi, dan suara mesin terasa agak berat. Stasioner adalah putaran engine sewaktu masih di darat. Kemudian putaran Idle engine dengan setelan idle 2.5 putaran menunjukan $6590 \mathrm{rpm}$ untuk engine seukuran itu, posisi idle ini akan digunakan ketika pesawat terbang normal. Hasil rpm maksimum dengan campuran 3:1 adalah $11011 \mathrm{rpm}$, putaran engine pada posisi throtle ini tinggi karena sewaktu akselerasi dibutuhkan rpm yang tinggi, kondisi akselerasi adalah posisi pesawat pada saat take off. 
TABEL 1. Pengujian dengan bahan bakar methanol dan minyak jarak perbandingan 3:1

\begin{tabular}{clc}
\hline & Posisi Throttle & rpm \\
\hline 1. & Stasioner & 3300 \\
\hline 2. & Idle & 6590 \\
\hline 3. & Akselerasi & 11011 \\
\hline
\end{tabular}

Hasil pengujian pada bahan bakar methanol dan minyak jarak dengan perbandingan 4:1 ditunjukkan oleh Tabel 2. Putaran engine yang di hasilkan pada campuran bahan bakar dengan perbandingan 4:1 ini lebih baik dari pada campuran bahan bakar dengan perbandingan 3:1 pada setiap kondisi throttle yaitu pada kondisi stasioner, idle dan pada saat akselerasi.

TABEL 2. Pengujian dengan bahan bakar methanol dan minyak jarak perbandingan $4: 1$

\begin{tabular}{clr}
\hline No. & \multicolumn{1}{c}{ Posisi Trothle } & rpm \\
\hline 1. & Stasioner & 4184 \\
\hline 2. & Idle & 7344 \\
\hline 3. & Akselerasi & 12649 \\
\hline
\end{tabular}

Hasil pengujian konsumsi bahan bakar methanol dan minyak jarak dengan perbandingan 3:1 dan perbandingan 4:1 secara berturut-turut disajikan pada Tabel 3 dan Tabel 4. Konsumsi bahan bakar dengan perbandingan methanol dan minyak jarak 3:1 menunjukan pada saat dipakai kombinasi kondisi throttle stasioner, manuver dan idle menghabiskan bahan bakar sebanyak $70 \mathrm{ml}$ dalam waktu 4 menit atau dengan kata lain konsumsi bahan bakarnya adalah 17,5 $\mathrm{ml} /$ menit, kemudian pada saat terbang dalam kondisi idle selama 8 menit menghabiskan 100 $\mathrm{ml}$ bahan bakar atau $12,5 \mathrm{ml} / \mathrm{menit}$. Dan apabila dipakai terbang dengan manuver secara terus menerus selama 5 menit menghabiskan $85 \mathrm{ml}$ bahan bakar atau $17 \mathrm{ml} / \mathrm{menit}$.

TABEL 3 . Konsumsi bahan bakar methanol dan minyak jarak perbandingan 3:1

\begin{tabular}{lcc}
\hline Posisi Throttle & $\begin{array}{c}\text { Waktu Terbang } \\
\text { (Menit) }\end{array}$ & $\begin{array}{c}\text { Volume BB } \\
(\mathrm{ml})\end{array}$ \\
\hline $\begin{array}{l}\text { Stasioner, Manuver } \\
\text { dan Idle }\end{array}$ & 4.00 & 70 \\
\hline Idle & 8.00 & 100 \\
\hline Full Manuver & 5.00 & 85 \\
\hline
\end{tabular}

TABEL 4 . Konsumsi Bahan Bakar Bahan Bakar dengan perbandingan 4:1

\begin{tabular}{lcc}
\hline Posisi Throttle & $\begin{array}{c}\text { Waktu Terbang } \\
\text { (Menit) }\end{array}$ & $\begin{array}{c}\text { Volume BB } \\
(\mathrm{ml})\end{array}$ \\
\hline $\begin{array}{l}\text { Stasioner, } \\
\text { Manuver dan Idle }\end{array}$ & 4.43 & 70 \\
\hline Idle & 9.00 & 100 \\
\hline Full Manuver & 5.50 & 80 \\
\hline
\end{tabular}

Tabel 4, menunjukkan perbandingan methanol dan minyak jarak sebesar 4:1 menghabiskan bahan bakar sebesar $15,8 \mathrm{ml} / \mathrm{menit}$ pada saat kondisi throttle stasioner, manuver dan idle konsumsi. Pada saat terbang dengan kondisi idle konsumsi bahan bakarnya sebanyak 11,11 $\mathrm{ml} /$ menit dan pada saat kondisi full manuver konsumsi bahan bakarnya sebanyak 14,5 $\mathrm{ml} / \mathrm{menit}$. Berdasarkan hasil tersebut, konsumsi bahan bakar pada engine pesawat ini lebih irit pada bahan bakar dengan perbandingan methanol dan minyak jarak sebesar 4:1 dikerenakan terjadi proses pembakaran lebih sempurna dibandingkan pada perbadingan bahan bakar methanol dan minyak jarak 3:1.

\section{KESIMPULAN}

Performa mesin terbaik pada pesawat prototype UAV dengan mesin OS 4.6 adalah dengan menggunakan bahan bakar dengan perbandingan campuran methanol dan minyak jarak sebesar 4:1 yang ditunjukan dengan capaian putaran engine yang lebih tinggi saat kondisi stasioner, idle dan akselerasi. Konsumsi bahan bakarnya juga lebih irit pada semua kondisi, baik saat take off, saat terbang idle dan juga saat melakukan manuver.

\section{DAFTAR PUSTAKA}

Agistya R.A. Eksperimental Pengaruh Variasi Sudut Kemiringan terhadap Temperatur Onset Termoakustik Generator Gelombang Berdiri. Quantum Teknika: Jurnal Teknik Mesin Terapan, 1(1), 1-9.

Hendriarto, A., Saksono, P., \& Gunawan, G. 2016. Analisa Perbandingan Penggunaan Bahan Bakar Solar Dengan Biodiesel B10 Terhadap Performansi Engine Cummins QSK 45 C. JTT (Jurnal Teknologi Terpadu), 4(1). 
Kholiq, I. 2015. Analisis Pemanfaatan Sumber Daya Energi Alternatif Sebagai Energi Terbarukan untuk Mendukung Subtitusi BBM. Jurnal Iptek, 19(2), 75-91.

Manan, S. 2009. Energi Matahari, Sumber Energi Alternatif Yang Effisien, Handal Dan Ramah Lingkungan Di Indonesia. Gema teknologi.

Rachmawati, P., \& Asyam, M. H. (2021). Sistem Kontrol Pesawat Tanpa Awak Untuk Menentukan Waypoint Berbasis Ardupilot. Quantum Teknika: Jurnal Teknik Mesin Terapan, 2(2), 80-86.

Warsita, A. 2012. Pengaruh Injection Timing dan Prosentase Campuran Minyak Diesel dengan Bahan Bakar Biodiesel terhadap Karateristik Mesin dan Emisi Gas Buang. TRAKSI, 12(2). 